\title{
A study on the starch and cellulose industries' wastewater treatment by biological methods
}

\author{
A. S. Kariman ${ }^{1} \&$ R. Dabbagh ${ }^{2}$ \\ ${ }^{1}$ Water Research Institute (WRI), Iran \\ ${ }^{2}$ University of Tehran, Iran
}

\begin{abstract}
Since the wastewater produced by the starch and cellulose industries has a high level of COD and turbidity, there are various methods for their treatment, one of which is a biological treatment method such as constructed wetlands. In this method, the plants are planted in sand or other different media. It is better that these media have a uniform constancy and the influent and effluent flow to the system and the residence time of wastewater in the biological system must also be adjusted. By increasing the residence time, the elimination rate of COD and turbidity will be increased. As a rule, if it is not possible to increase the residence time, increasing the efficient surface or vegetation accumulation will be better. This project has been carried out from May 1998 to May 1999. Results showed reed (Phragmites spp.) planted wetland as having the ability to treat starch and cellulose industry wastewater.

The mean value of COD in the constructed wetland effluent was $93.17 \mathrm{mg} / \mathrm{L}$ (78\% removal) and the values of turbidity, nitrite and $\mathrm{pH}$ were $23.04 \mathrm{NTU}, 0.19$ $\mathrm{mg} / \mathrm{L}$ and 7.5 respectively. Turbidity removal ranged from $73-98 \%$ and the removal of nitrite ranged from $10-55 \%$. The efficiency of the reed planted wetland for treating the above mentioned wastewater was reasonable and in good operational conditions its effluent could be used in agricultural irrigation or discharged into surface water or leaching pits.
\end{abstract}

Keywords: wastewater treatment, starch, cellulose, industries, constructed wetlands, COD, bench scale. 


\section{Introduction}

Natural wetlands have received wastewater ever since people began to live in towns and cities. Scientists soon realized that natural wetlands were more than just a convenient disposal site and the wetlands were actually cleaning the water. As a result, researchers began to investigate using natural and constructed wetlands purposely to improve water quality. Wetlands, both natural and constructed, have demonstrated effective treatment of contaminated waters.

Wetland systems offer numerous benefits, especially in this age of concern about wetland losses and the focus on preserving open space. Constructed and natural treatment wetlands provide several major benefits compared to more conventional treatment alternatives, for example they are less expensive to construct, require less maintenance and are less expensive to operate than traditional treatment systems.

Constructed wetlands are an available alternative for treating contaminated water from a variety of sources, including municipalities, agricultural operation, and industrial sites. Constructed surface flow treatment wetlands are typically shallow, man-made impoundments planted with emergent, rooted vegetation. Water flows overland through the wetland, primarily above the sediment surface. These wetlands may be planted manually or naturally colonized by volunteer plant communities. Some constructed surface flow treatment wetlands contain monocultures of reeds (Phragmites spp.), cattails (Typha spp.) or bulrushes (Scirpus spp.), while others are planted with diverse plant communities that are more adaptable under changing seasonal and water quality conditions [1-6].

This paper describes a bench scale study to treat starch and cellulose industry effluents. Due to climatic conditions in Iran and more available space for constructed wetlands, this method could be a suitable alternative to treat effluents from the above mentioned industries or other municipal and industrial effluents.

\section{Research methods}

This research consists of two steps:

- The design, structure and start-up of bench scale FWS constructed wetland system.

- The study of bench scale FWS constructed wetland according to operation parameters.

The above experiments took about one year to complete, from May 1998 up to May 1999. The constructed wetland has been operated continuously from 11 November 1998 to 4 January 1999. Samples were collected twice per week from constructed wetland $(\mathrm{CW})$ influent, reed planted $\mathrm{CW}$ effluent, and $\mathrm{CW}$ effluent without reeds (as a control or blank). Samples were sent to a laboratory at low temperature (cool condition) to analyze as soon as possible.

$\mathrm{COD}, \mathrm{DO}$, turbidity, nitrite, $\mathrm{pH}$ and temperature were analyzed on the basis of water and wastewater examination guidelines [7, 8]. In order to study the CW efficiency, the results and percentage of pollutant reduction were determined 
firstly and after that measured qualitative operation parameters in the effluent were compared with Iran Department of Environment (DOE) guidelines and WHO criteria for wastewater discharge or wastewater reuse.

\section{Results and discussion}

The results obtained from bench scale $\mathrm{CW}$ operation steps for raw sewage input (influent) and $\mathrm{CW}$ effluents both reed planted and without reeds have been presented as mean values in table 1 and are also shown in figures 1-7.

Table 1: Qualitative parameters for mean values of raw sewage influent, reed constructed wetland effluent (CWE) and CWE without reeds.

\begin{tabular}{|c|c|c|c|c|c|c|c|}
\hline Item & $\begin{array}{c}\text { Sampling } \\
\text { location }\end{array}$ & $\begin{array}{c}\mathrm{NO}_{2} \\
(\mathrm{mg} / \mathrm{L})\end{array}$ & $\begin{array}{c}\mathrm{COD} \\
(\mathrm{mg} / \mathrm{L})\end{array}$ & $\begin{array}{c}\mathrm{DO} \\
(\mathrm{mg} / \mathrm{L})\end{array}$ & $\begin{array}{c}\text { Turbidity } \\
(\mathrm{NTU})\end{array}$ & $\mathrm{pH}$ & $\begin{array}{c}\text { Temp. } \\
{ }^{\circ} \mathrm{C}\end{array}$ \\
\hline 1 & Influent & 0.8 & 675 & 1.37 & 184.5 & 6.7 & 15 \\
\hline 2 & $\begin{array}{c}\text { Without } \\
\text { reeds CWE } \\
\text { (blank) }\end{array}$ & 0.5 & 184 & 0.7 & 9.20 & 7.5 & 14.5 \\
\hline 3 & $\begin{array}{c}\text { With reeds } \\
\text { CWE }\end{array}$ & 0.19 & 93.17 & 1.55 & 23.04 & 7.5 & 14.3 \\
\hline
\end{tabular}

Analyses of results indicated that there were no significant differences between the obtained mean values of parameters such as $\mathrm{COD}, \mathrm{NO}_{2}, \mathrm{DO}, \mathrm{pH}$, turbidity and temperature in comparison to the Iran Department of Environment criteria or guidelines to discharge or reuse treated wastewater.

Table 2: Discharge standards for industrial effluents on the basis of Iran DOE.

\begin{tabular}{|c|l|c|c|c|}
\hline & \multicolumn{1}{|c|}{ Parameters } & $\begin{array}{c}\text { Discharge of } \\
\text { surface water }\end{array}$ & Leaching pits & $\begin{array}{c}\text { Agriculture } \\
\text { use }\end{array}$ \\
\hline 1 & $\mathrm{pH}$ & $5-8.5$ & $5-9$ & $6-8.5$ \\
\hline 2 & $\mathrm{DO}, \mathrm{mg} / \mathrm{L}$ & - & - & 2 \\
\hline 3 & $\mathrm{COD}, \mathrm{mg} / \mathrm{L}$ & $\begin{array}{c}60 \\
(100 \\
\text { Instantaneous })\end{array}$ & $\begin{array}{c}60 \\
(100 \\
\text { Instantaneous })\end{array}$ & 200 \\
\hline 4 & Turbidity, NTU & 50 & - & 50 \\
\hline 5 & $\mathrm{NO}_{2}, \mathrm{mg} / \mathrm{L}$ & 10 & 10 & - \\
\hline
\end{tabular}

Figure 1 shows reduction of COD in terms of operation periods of CW. Iran DOE guideline (table 2) for COD discharge is less than $200 \mathrm{mg} / \mathrm{L}$ for agricultural use. The mean value of COD reduction in treated wastewater was about $93.17 \mathrm{mg} / \mathrm{L}$ and it is acceptable to reuse or discharge. In figures 2 and 3 turbidity and nitrite reduction have been presented respectively. The reduction of turbidity in all cases is suitable and less than 50 NTU on the basis of Iran DOE guidelines for discharge of treated wastewater. Increasing turbidity in reeds planted CWE in comparison without reeds CWE could be related to bacteria or algae growth. The 
nitrite value in the effluent was less than the guideline value of $10 \mathrm{mg} / \mathrm{L}$. The fluctuation of dissolved oxygen (DO) is a function of temperature and in almost all samples the DO concentration was more than $1 \mathrm{mg} / \mathrm{L}$. Generally, the DO concentration in effluent (reeds CWE) has been increased (Fig.6). The effluent $\mathrm{pH}$ from reeds $\mathrm{CWE}$ has been naturalized in comparison to the influent and without reeds CWE $\mathrm{pH}$ (Fig.7). In fact effluent $\mathrm{pH}$ was in the range 5-8.5. This range conforms to the recommended Iran DOE effluent $\mathrm{pH}$ for reuse or discharge of treated wastewater.

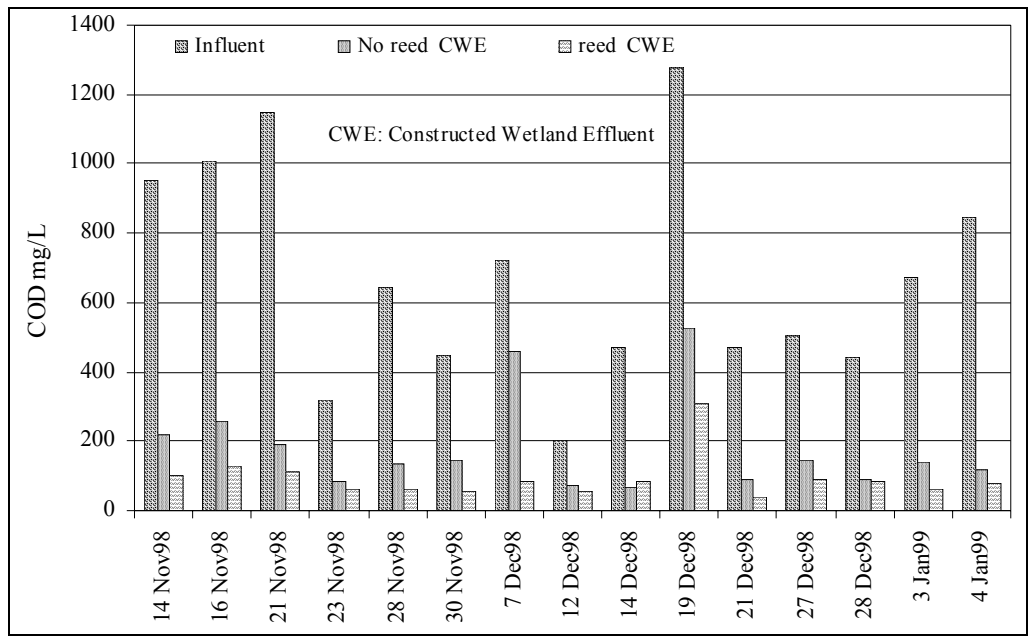

Figure 1: Reduction of COD in the reeds planted CWE and without reeds CWE as a control.

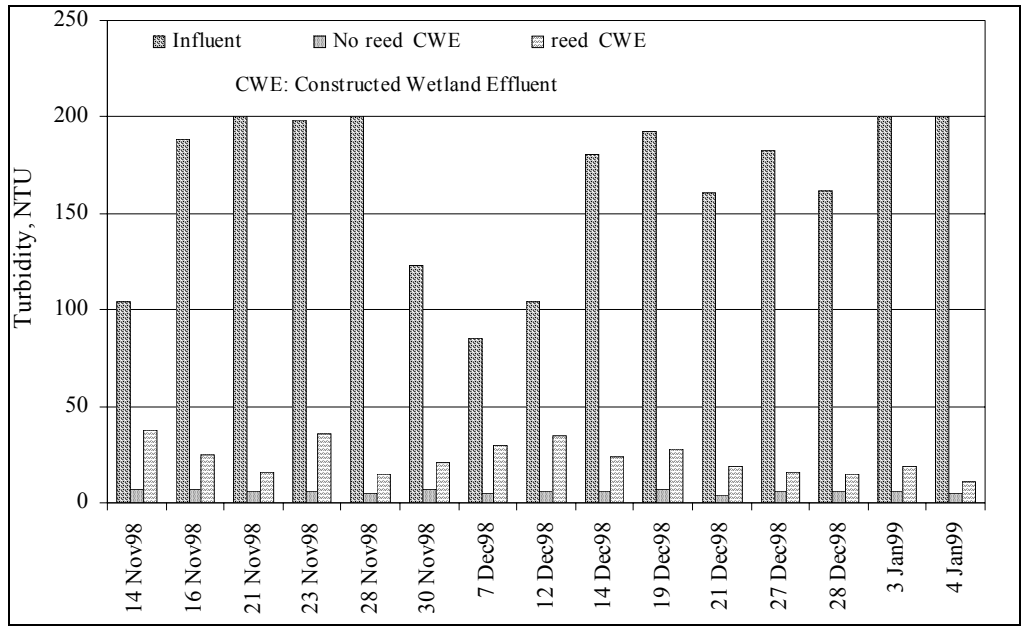

Figure 2: $\quad$ Reduction of turbidity in the reeds planted CWE and without reeds CWE as a control. 


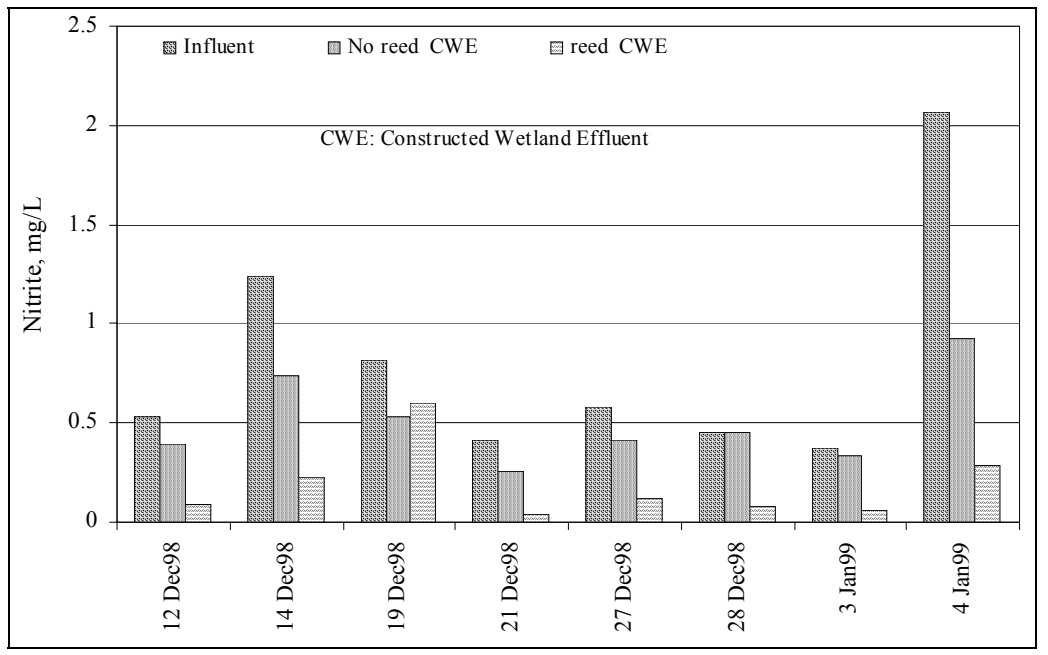

Figure 3: Reduction of nitrite in reeds planted CWE and no reeds CWE as a control.

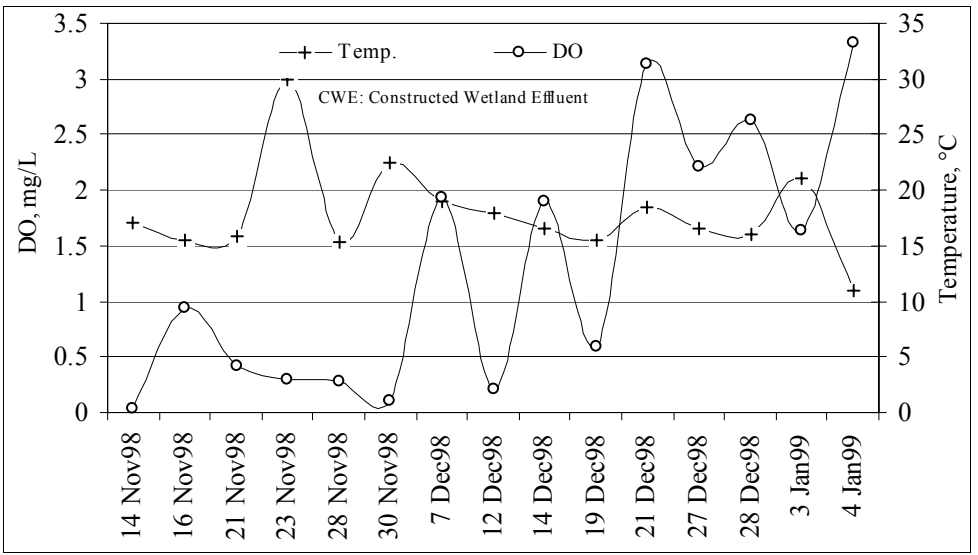

Figure 4: Fluctuation of DO as a function of temperature in the influent during operation.

\section{Conclusions}

Results showed constructed wetlands could be used as an alternative treatment for starch and cellulose industries wastewater. Table 3 shows the percentage reduction of pollutants in the operational period. According to Iran DOE effluent criteria (table 2), the possibility of using effluent from constructed wetland to discharge to surface water, leaching pits and agricultural irrigation (table 4) was established. More and complementary research is needed to use this method in a full or industrial scale. 
824 Waste Management and the Environment IV

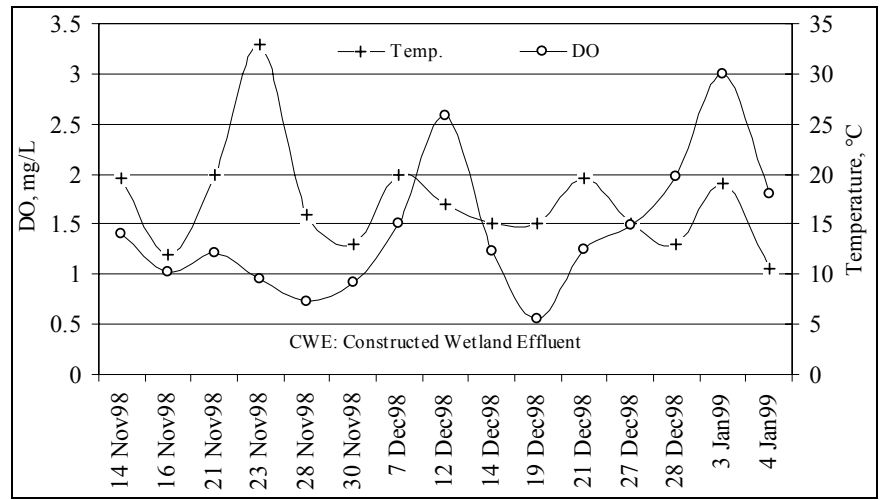

Figure 5: Fluctuation of $\mathrm{DO}$ as a function of temperature in the without reeds CWE during operation.

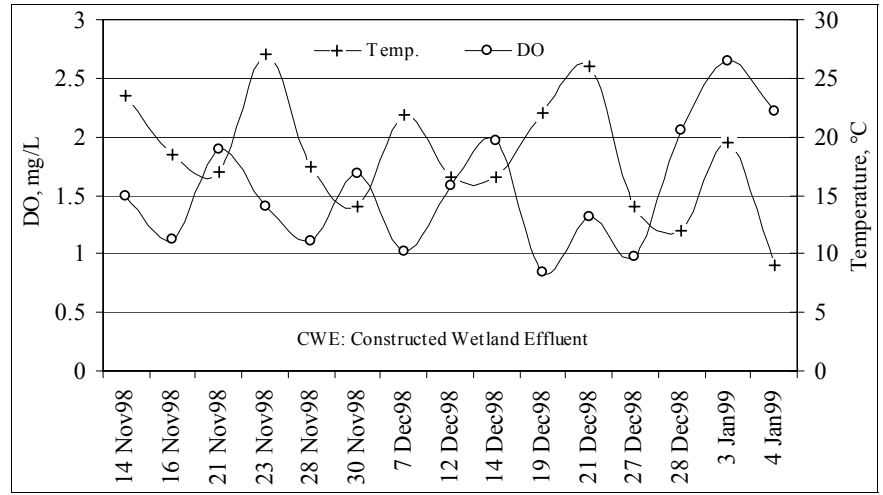

Figure 6: Fluctuation of DO as a function of temperature in the reeds planted CWE during operation.

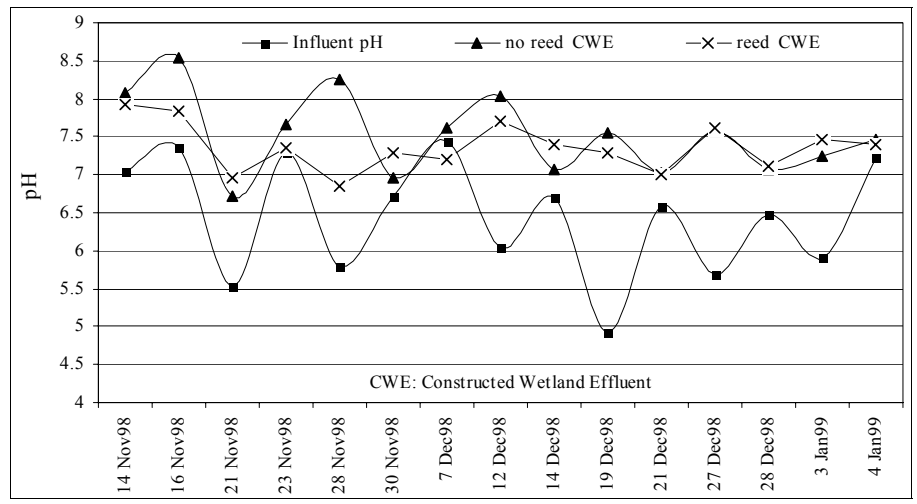

Figure 7: Fluctuation of $\mathrm{pH}$ in the reeds planted $\mathrm{CWE}$ and without reed CWE during operation. 
Table 3: $\quad$ Percentage reduction of COD, turbidity and nitrite in the reeds planted and without reeds constructed wetland effluent (CWE).

\begin{tabular}{|c|c|c|c|c|c|c|c|c|c|}
\hline & $\mathrm{Parameters}_{\text {Date }}^{\text {Date }}$ & $11 / 14$ & $11 / 16$ & $11 / 21$ & $11 / 23$ & $11 / 28$ & $11 / 30$ & $12 / 7$ & $12 / 12$ \\
\hline \multirow{3}{*}{ 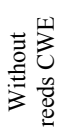 } & COD & $76 \%$ & $74 \%$ & $83 \%$ & $73 \%$ & $79 \%$ & $67 \%$ & $36 \%$ & $63.5 \%$ \\
\hline & Turbidity & $93 \%$ & $96 \%$ & $97 \%$ & $97 \%$ & $73 \%$ & $94 \%$ & $93 \%$ & $94 \%$ \\
\hline & $\mathrm{NO}_{2}$ & & & & & & & $24 \%$ & $40 \%$ \\
\hline \multirow{3}{*}{ 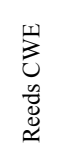 } & COD & $89 \%$ & $87 \%$ & $90 \%$ & $80 \%$ & $97 \%$ & $87 \%$ & $96 \%$ & $73 \%$ \\
\hline & Turbidity & $63 \%$ & $86 \%$ & $92 \%$ & $82 \%$ & $92 \%$ & $82 \%$ & $64 \%$ & $66 \%$ \\
\hline & $\mathrm{NO}_{2}$ & & & & & & & & $83 \%$ \\
\hline
\end{tabular}

\begin{tabular}{|c|c|c|c|c|c|c|c|c|}
\hline & $\underbrace{\text { Date }}_{\text {Parameters }}$ & $12 / 14$ & $12 / 19$ & $12 / 21$ & $12 / 27$ & $12 / 28$ & $1 / 3$ & $1 / 4$ \\
\hline \multirow{3}{*}{ 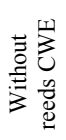 } & COD & $86 \%$ & $59 \%$ & $80 \%$ & $71 \%$ & $79 \%$ & $79 \%$ & $85 \%$ \\
\hline & Turbidity & $96 \%$ & $96 \%$ & $97 \%$ & $96 \%$ & $93 \%$ & $97 \%$ & $98 \%$ \\
\hline & $\mathrm{NO}_{2}$ & $35 \%$ & $36.5 \%$ & $30 \%$ & $29 \%$ & $0 \%$ & $10 \%$ & $55 \%$ \\
\hline \multirow{3}{*}{ 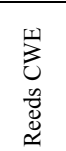 } & COD & $82 \%$ & $76 \%$ & $92 \%$ & $84 \%$ & $81 \%$ & $96 \%$ & $97 \%$ \\
\hline & Turbidity & $86 \%$ & $85 \%$ & $87 \%$ & $91 \%$ & $90 \%$ & $90 \%$ & $94 \%$ \\
\hline & $\mathrm{NO}_{2}$ & $81 \%$ & $80 \%$ & $90 \%$ & $79 \%$ & $82 \%$ & $83 \%$ & $85 \%$ \\
\hline
\end{tabular}

Table 4: Possibility of discharge or reuse of treated wastewater by constructed wetland in the surface water $(\mathrm{S})$, Leaching pits (L) and agricultural use (A).

\begin{tabular}{|c|l|c|c|c|}
\hline Parameters & $\begin{array}{c}\text { Discharge to } \\
\text { surface water }\end{array}$ & $\begin{array}{c}\text { Leaching pits } \\
\text { discharge }\end{array}$ & $\begin{array}{c}\text { Agricultural } \\
\text { use }\end{array}$ \\
\hline 1 & $\mathrm{pH}$ & $\mathrm{S}$ & $\mathrm{L}$ & $\mathrm{A}$ \\
\hline 2 & $\mathrm{DO}$ & $\mathrm{S}$ & - & $\mathrm{A}$ \\
\hline 3 & COD & $\mathrm{S}$ & - & $\mathrm{A}$ \\
\hline 4 & Turbidity & $\mathrm{S}$ & $\mathrm{L}$ & $\mathrm{A}$ \\
\hline 5 & $\mathrm{NO}_{2}$ & $\mathrm{~S}$ & $\mathrm{~L}$ & - \\
\hline
\end{tabular}

\section{References}

[1] Moshiri, G.A., Constructed wetlands for water quality improvements. Lewis publishers, Boca Raton, FL 1993.

[2] Crites, R., Tchobanoglous, G., Small and decentralized wastewater management systems, McGraw-Hill Co. pp. 563-608, 1998.

[3] Metaclaf \& Eddy inc., Wastewater engineering, treatment, disposal and reuse, Tchobanoglous, G., Burton (rev.) Franklin L., pp. 927-1016, 1991. 
826 Waste Management and the Environment IV

[4] Wetland Solutions, Inc. http://wetlandsolutionsinc.com/wwd_treatment wetlands.html

[5] Etix. H. Wastewater treatment in constructed wetlands: system Design, removal processes. And treatment performance, ed. G.A. Moshiri, 1993.

[6] EPA, Constructed wetlands for wastewater Treatment and Wildlife Habitat. EPA832-R93-005, Municipal Technology Branch, Washington D.C. 1993.

[7] APHA, AWWA, WEF, Standard Methods for water and wastewater Examination, 1992.

[8] Dean V. Adams, Water and wastewater examination manual, CRC press and Lewis publication Inc., U.S.A. 1990. 